\title{
Justicia y sabiduría Los sabios de Israel y la justicia
}

\section{José Luis Sicre Díaz, S. J. Pontificio Instituto Bíblico, Roma.}

Con motivo del asesinato de los mártires que hoy recordamos, la revista ECA publicó un In memoriam, en el que podemos leer las siguientes palabras: "Se comprometieron defendiendo a las mayorías pobres salvadoreñas desde la universidad. Su actividad universitaria fue seria, científica y académica, pues fue lo más temido de ellos. Los asesinaron por su palabra razonable y verdadera"'

En un contexto universitario, y como homenaje a quienes consideraron que los conocimientos científicos y técnicos deben ponerse al servicio de los más débiles y de una sociedad justa, abordaré la relación entre justicia y sabiduría dentro de los libros sapienciales de la Biblia. Mi intención inicial era tratarlos todos, presentando una visión de cómo fue evolucionando el pensamiento sapiencial desde los primeros esbozos, a través de proverbios y refranes, algunos de los cuales podrían remontarse al siglo $\mathrm{X}$ a. C. e incluso antes, hasta el libro de la Sabiduría, muy cercano a los orígenes del cristianismo. Sin embargo, la abundancia del material me ha obliga a enfocar el tema de modo muy distinto, a partir de tres preguntas básicas: cómo ven los sabios la sociedad de su tiempo por lo que respecta al problema de la justicia, qué solución entrevén y qué pretenden enseñar. Antes de responder a estas preguntas, presentaré una rápida visión de la sabiduría en Israel.

\section{El concepto de sabio y los libros sapienciales}

Nuestro término "sabio" no describe adecuadamente la realidad de estos personajes del antiguo Israel. Allí, como en el Antiguo Oriente, los sabios no son personas despistadas, abstraídas en su ciencia, alejadas de las preocupaciones diarias, profundos conocedores de su especialidad, pero supinos ignorantes de

1. In memoriam, ECA, $493-494$ (1989), 1011ss. 
otras materias y sin ningún sentido práctico. Esta caricatura del sabio, bastante extendida entre nosotros, ni siquiera es válida para los "sabios" contemporáneos. Mucho menos para los antiguos.

Al hablar de los sabios de Israel nos referimos a un grupo de personas bastante heterogéneo, que abarca desde el educador hasta el filósofo o el teólogo, pasando por los preceptores de los príncipes o de la nobleza y por los consejeros de la corte. En este sentido se puede decir que los sabios se mueven en un ambiente social elevado, detalle que puede condicionar el contenido y el método de sus reflexiones. Pero no olvidemos que junto a esta sabiduría cortesana existe otra popular, producto de la observación, de la experiencia y de los años.

Sus reflexiones han quedado recogidas en los libros de los Proverbios, Job, Qohélet (Eclesiastés), Eclesiástico (Ben Sirá), Sabiduría y también en diversos Salmos y relatos. Es imposible hablar de todos ellos. Me limitaré a presentar las cuatro obras en las que basaré mis reflexiones: Proverbios, Job, Eclesiastés y Eclesiástico.

\subsection{Proverbios}

El título original es Proverbios de Salomón, hijo de David, rey de Jerusalén $(1,1)$. En realidad, ni el libro es de Salomón, ni contiene solo proverbios. Podemos distinguir ocho colecciones, tres bastante amplias y cinco pequeñas, que se han añadido como apéndices a las más importantes. La primera (cc. 1-9) se considera generalmente la más tardía. Utilizaré el material contenido en los capítulos 10-31. En líneas generales, como veremos más adelante, estos proverbios ofrecen un punto de vista optimista: el justo es premiado y el malvado castigado.

\subsection{La crisis: Job y Eclesiastés}

El optimismo de los antiguos proverbios sufrirá un duro golpe con la deportación a Babilonia. En el año 586 a. C. desaparece también la independencia política y la monarquía y el templo es incendiado, igual que Jerusalén, la ciudad del Dios Altísimo.

En el contexto de esta crisis, que dura más de un siglo, se escribe el libro de Job, probablemente en el siglo $\mathrm{V}$ a. C. ${ }^{2}$. A diferencia de lo que piensan muchos que no lo han leído, Job no es el modelo del justo paciente, sino del justo rebelde. Al principio acepta con paciencia y humildad la muerte de sus hijos, la pérdida de los bienes, e incluso de la salud. Pero vienen a consolarlo tres amigos, representantes de la teología optimista tradicional, y estos consiguen lo que no había conseguido el Satán: que Job maldiga a Dios. Frente a la idea de que Dios

2. Para la introducción al libro de Job y sus problemas, me remito a lo que escribí en L. A. Schökel y J. L. Sicre Díaz, Job (Madrid: Cristiandad, 2002). 
siempre actúa con justicia, y que si Job sufre es por culpa de sus pecados, el protagonista se rebela y acusa a Dios de injusticia y desmesura.

Siglos más tarde, a finales de la época persa o en la griega, Qohélet representa un modo totalmente distinto de entrar en crisis ${ }^{3}$. No a partir del dolor, sino del hastío. La ficción literaria describe el esfuerzo inicial del protagonista por encontrar un sentido a la vida. Sin embargo, ni la sabiduría, ni el placer, ni la riqueza consigue dárselo. Y así "concluí por desengañarme de todo el trabajo que me fatiga bajo el sol" $(2,20)$. Su obra, muy breve, recoge una serie de reflexiones sobre los temas más diversos, formuladas a veces de manera tan concisa y enigmática que se prestan a interpretaciones muy distintas.

\subsection{Eclesiástico}

Esta obra es la única del Antiguo Testamento católico 4 cuyo autor conocemos por su nombre. En el prólogo, el traductor dice que la obra fue escrita por su abuelo, Jesús (ben Sirá), y que la traducción la llevó a cabo a partir del año 38 del reinado de Evergetes, esto es, el 132 a. C. Por consiguiente, el original hebreo se suele situar entre los años 190 y $170^{5}$. El prólogo nos informa también sobre la personalidad del autor. "Mi abuelo Jesús, después de dedicarse intensamente a leer la Ley, los Profetas y los restantes libros paternos, y de adquirir un buen dominio de ellos, se decidió a componer por su cuenta algo en la línea de la sabiduría e instrucción, para que los deseosos de aprender, familiarizándose también con ello, pudiesen adelantar en la vida según la Ley" (Prólogo 7-10, o letra c). No hay en estas palabras ningún acento polémico; pero si se leen en el trasfondo cultural de la época, con el avance creciente de la helenización, no cabe duda de que Jesús ben Sirá intentó revitalizar la tradición típicamente judía frente a los que corrían el peligro de despreciarla.

3. Una introducción muy completa a todos los problemas del libro se encuentra en el comentario de J. Vílchez, Eclesiastés o Qohélet (Estella: Verbo Divino, 1994, pp. 21-101). Muy amplia también la presentación de V. Morla en Libros sapienciales y otros escritos (Estella: Verbo Divino, 1994, pp. 181-216).

4. Los judíos y protestantes no aceptan este libro como inspirado. Excelente introducción en V. Morla, Libros sapienciales y otros escritos, op . cit., pp. 217-259. J. Vílchez, Sabiduría y sabios en Israel, Estella: Verbo Divino, 1995, pp. 121-172, ofrece una visión muy sugerente de los recursos estilísticos y del mensaje del libro.

5. Esta datación se basa en dos años: por arriba (190), la alabanza del sumo sacerdote Simeón (50, 1-24), que todos los comentaristas identifican con Simón II, el sumo sacerdote de aquellos tiempos (hacia 195 a. C.), da por supuesto que ya ha muerto; por abajo (170), el hecho de que no se aluda a las duras medidas de Antíoco IV contra Onías II, el último sumo sacerdote legítimo. 


\section{Visión de la sociedad}

Si tenemos en cuenta que los escritos sapienciales abarcan un período de casi diez siglos, es lógico que se den puntos de vista muy distintos. La sociedad de entonces no variaba a la velocidad que ha cambiado la nuestra, en los últimos siglos o incluso en las últimas décadas. Sin embargo, desde los comienzos de la monarquía en Israel hasta el dominio del imperio romano, se produjeron cambios notables, que afectaron las diferencias sociales y las formas de gobierno.

\subsection{La existencia de la pobreza y la vida dura de los pobres}

Los capítulos 10-30 del libro de los Proverbios representan el pensamiento más antiguo. Recogen la mentalidad de la época monárquica, cuando Judá goza de independencia política. El proverbio, por su misma formulación breve y concisa, no se presta para el análisis de la situación socio-económica, de los problemas de justicia e injusticia, de la opresión de los pobres o de las arbitrariedades de los poderosos. Por otra parte, el libro no habla mucho de los pobres ${ }^{6}$. Sin embargo, ofrece datos interesantes. Subrayan la vida dura del pobre, abandonado de sus amigos, odioso a sus compañeros, incluso a sus hermanos. "La riqueza procura muchos amigos, al pobre lo abandonan sus amigos" (19,4). "El pobre es odioso aun a su compañero, el rico tiene muchos amigos" $(14,20)$. "El pobre es odioso aun a sus hermanos, cuánto más se distanciarán de él los amigos" $(19,7)$.

El pobre puede padecer toda clase de injusticias, en la vida diaria y en los tribunales $(22,22)$, ser víctima de la codicia de los ricos y poderosos, "gente con navajas por dientes y cuchillos por mandíbulas, para extirpar de la tierra a los humildes y del suelo a los pobres" $(30,14)$. Sin embargo, el pobre no es un ser despreciable: "Más vale ser humilde con los pobres que repartir botín con los soberbios" $(16,19)$.

¿A qué se debe la pobreza? No encontramos en los proverbios un análisis de este hecho. Solo la advertencia de que la holgazanería lleva a la pobreza: "Mano perezosa empobrece, brazo diligente enriquece" $(10,4)$. "Un rato duermes, un rato descansas, un rato cruzas los brazos y descansas, y te llega la pobreza del vagabundo, la indigencia del mendigo" (24, 33-34).

6. David Noel Freedman, en su artículo "Pobre, Pobreza", en el Anchor Bible Dictionary, distingue los siguientes tipos de pobres según la terminología bíblica: el mendigo ('ebyôn), el campesino pobre (dal), el pobre holgazán (mahsôr), el pobre económico $(r a$ 'š) y el pobre oprimido ('anî). De estos términos, en Proverbios,

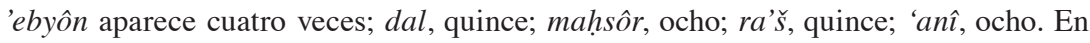
cambio, curiosamente, es el libro bíblico que más habla de la pobreza. El término "pobreza" (rî̌s/rêš) solo se usa siete veces en todo el Antiguo Testamento, y siempre en el libro de los Proverbios, maḥsôr, "carencia, privación de bienes", solo trece veces, ocho de ellas en Proverbios. 
Pero en Proverbios 17, 23 encontramos el siguiente refrán: "El malvado acepta soborno bajo cuerda para torcer el curso de la justicia". Este proverbio denuncia uno de los problemas fundamentales en el antiguo Israel: la corrupción de la administración de la justicia, que, como denunciaron los profetas, repercutía en la situación económica de los sectores más débiles de la sociedad, llevándolos a la ruina.

A Job, como dijimos al comienzo, no le preocupa la sociedad, le preocupa su propia desgracia. Pero el capítulo 24 describe mejor que ningún otro texto del Antiguo Testamento la triste condición de la gente pobre, causada por la injusticia de los malvados.

Los malvados mueven los linderos, roban rebaños y los apacientan; se llevan el asno del huérfano y toman en prenda el buey de la viuda, echan del camino a los pobres y los miserables tienen que esconderse.

Como onagros del desierto salen a su tarea, madrugan para hacer presa, el páramo ofrece alimento a sus crías;

cosechan en campo ajeno y rebuscan en el huerto del rico; pasan la noche desnudos, sin ropa con que taparse del frío, los cala el aguacero de los montes y, a falta de refugio, se pegan a las rocas. Andan desnudos por falta de ropa; cargan gavillas y pasan hambre; exprimen aceite en el molino, pisan en el lagar, y pasan sed (Job 24, 2-11).

El pasaje se centra en describir la dura vida de los pobres. Pero al comienzo denuncia quiénes son los responsables de esta situación: los malvados, que se apoderan de las tierras y rebaños de los pobres, roban los animales de huérfanos y viudas.

En cambio, los poderosos, aunque sean unos canallas, disfrutan de toda clase de bienes, e incluso después de la muerte son honrados por la sociedad.

¿Por qué siguen vivos los malvados y al envejecer se hacen más ricos?

Su prole está segura en su compañía y ven crecer a sus retoños; sus hogares, en paz y sin temor, la vara de Dios no los azota;

su toro cubre sin marrar, la vaca les pare sin abortar.

Dejan correr a sus chiquillos como cabritos, dejan saltar a sus críos; cantan al son de cítaras y panderos y se regocijan oyendo la flauta.

Así consumen su vida dulcemente y bajan serenamente al sepulcro [...].

Sé que decís: ¿dónde está la casa del poderoso, dónde la morada de los malvados?

¿Por qué no se lo preguntan a los que han viajado

y no creen sus historias maravillosas?:

Que en la catástrofe se salva el malvado y que el día trágico lo encuentra ausente;

que nadie le echa en cara su conducta ni le paga lo que se merece; 
que lo conducen al sepulcro y se hace guardia junto al mausoleo

y le son dulces los terrones del valle.

Después de él marcha todo el mundo, y antes de él incontables (21, 7-13.28-33).

La visión de Qohélet es tan pesimista o incluso más que la de Job, porque no se limita a criticar a los malvados, sino que enumera una serie de problemas concretos, aunque no con el orden y la lógica que a nosotros nos gusta, sino de forma caótica, mezclando los temas. A lo largo del libro aparecen la corrupción de los tribunales de justicia; la estructura global de la sociedad, en la que un hombre termina dominando a otros; la estima de la que gozan los malvados, incluso después de muertos; la permisividad y benevolencia con los criminales; la concesión de puestos de responsabilidad a personas sin preparación. Todo esto repercute en la triste situación de los oprimidos. Como indica Garret, para Qohélet, en medio del sinsentido de la vida, la única solución es disfrutar de los placeres sencillos y cotidianos de la comida, la bebida, los amigos... Pero todo eso se les arrebata a los oprimidos, convirtiendo su vida en pura amargura ${ }^{7}$. La falta de tiempo nos impide tratar en qué medida este punto de vista está condicionado por las circunstancias político-económicas de la época": "Otra cosa observé bajo el sol: en la sede del derecho, el delito; en el tribunal de la justicia,

7. "Qoheleth considers the oppression of the weak by the powerful to be among the worst evils of life in this world. Oppression, he asserts, makes a world that is already difficult unbearable. For all the sorrows that people face, and despite the ultimate absurdity that all is made meaningless by death, one may still find a measure of joy in life. Food, drink, companions, a good day's work followed by a good night's sleep - these things all give real if passing pleasure in their time. Oppression, however, deprives people of even these pleasures and makes all of life bitter. Abuse of one's rights at the hands of those who are untouchable in their power makes death seem preferable to life" (D. A. Garret, "Qoheleth on the Use and Abuse of Political Power", Trinity Journal, 8 NS [1987], 159-177, cf. 176).

8. "Qoheleth's era was characterized by unprecedented economic volatility. Fortunes were made and lost; fee risk was high, fee potential for wealth, enormous. In this bustling economy, social standing was often fleeting. Talented individuals accumulated vast wealth at fee expense of enjoyment, working incessantly and spending restless nights worrying about losing it to thieves and seeing it squandered by costly employees. Investments in mercantile enterprises on fee high seas provided a risky alternative to pastoral and agricultural endeavors, themselves subject to fee whim of nature. Obsession with capturing fee optimal moment to venture forth in either of these tasks threatened fee whole activity, as did fee attempt to bolster human labor by magic, whether spells or a divining rod" (J. L. Crenshaw, "Qoheleth in historical context”, Biblica [2007], 285-299, cf. 289). 
la iniquidad" $(3,16-17)$. "Todo esto lo he observado fijándome en todo lo que sucede bajo el sol, mientras un hombre domina a otro para su mal" $(8,9)^{9}$.

También he observado esto: sepultan a los malvados, los llevan a lugar sagrado, y la gente marcha alabándolos por lo que hicieron en la ciudad. Y esta es otra vanidad: que la sentencia dictada contra un crimen no se ejecuta enseguida; por eso, los hombres se dedican a obrar mal, porque el pecador obra cien veces mal y tienen paciencia con él. [...] En la tierra sucede otra vanidad: hay honrados a quienes toca la suerte de los malvados, mientras que a los malvados les toca la suerte de los honrados. Y esto lo considero vanidad (8, 10-14).

"Hay un mal que he visto bajo el sol, un error del que es responsable el gobernante: el necio ocupa altos cargos mientras que los ricos ocupan puestos humildes, he visto esclavos a caballo mientras príncipes iban a pie como esclavos" (Ecl 10, 5-7) $)^{10}$.

Finalmente, Jesús ben Sirá ofrece en el capítulo 13 una panorámica de la sociedad (Eclo 13, 15-24). Parte de un principio general: todos los seres del mundo, sean animales o humanos, están divididos y enfrentados, y el débil es presa del fuerte. Entre los humanos existen dos grandes grupos: ricos y pobres. Los primeros son calificados de soberbios, los segundos de humildes. Y ocurre igual que entre los animales: "El asno salvaje es presa del león, el pobre es pasto del rico" (v. 19). El rico se alimenta del pobre, abusa de él, se beneficia de él. A pesar de ello, "el rico aborrece al indigente" (v. 20). Ante estos dos grupos, la sociedad se pone de parte del rico, lo elogia y alaba, mientras que desprecia al pobre y lo rechaza. Una visión muy pesimista, al estilo Eclesiastés.

15 Todo viviente ama a los de su especie:

lo mismo el hombre, a los que se le asemejan;

17 no se junta el lobo con el cordero

ni el malvado con el justo (ni el rico con el necesitado).

18 ¿Pueden tratarse la hiena y el perro?, ¿pueden tratarse el rico y el pobre?

9. La interpretación del v. 9 es discutida, como ocurre a menudo en Qohélet. Thomas Krüger, tras indicar que la Carta de Aristeas 262-263 aconseja al rey Ptolomeo no considerarse un dios y actuar siempre sabiendo que es un ser humano que gobierna a seres humanos, comenta: "Qohelet $8,9 *$ da un paso más: si el conocimiento y el poder de un ser humano son fundamentalmente limitados (vv. 6-8*), el gobierno de una persona sobre otras es en sí mismo discutible. De este modo, el contenido del texto se relaciona con la tradición del AT que critica la realeza y a los gobernantes, sin ofrecer una alternativa al 'gobierno de una persona sobre otras"" (Qoheleth, Minneapolis: Fortress Press, 2004, p. 157).

10. El pasaje recuerda a las quejas del egipcio Ipu-Wer: "Verdaderamente, los pobres poseen ahora tesoros. El que ni siquiera era capaz de hacer un par de sandalias ahora posee riquezas. Verdaderamente, los nobles se lamentan mientras los pobres se alegran". 
19 El asno salvaje es presa del león, el pobre es pasto del rico.

20 El soberbio aborrece al humilde, el rico aborrece al indigente.

21 Tropieza el rico, y su vecino lo sostiene; tropieza el pobre, y su vecino lo empuja;

22 habla el rico, y muchos lo aprueban, y encuentran elocuente su hablar desmañado; se equivoca el pobre y le dicen: vaya, vaya; habla con acierto, y no le hacen caso; habla el rico, y lo escuchan en silencio, y ponen por las nubes su talento; habla el pobre, y dicen: ¿quién es?, y si cae, encima lo empujan.

24. Buena es la riqueza adquirida sin culpa, mala es la pobreza causada por la arrogancia.

\subsection{Las causas de la injusticia}

En unas obras tan distintas y separadas entre sí por siglos de distancia, es lógico que encontremos ideas muy diferentes sobre las causas de la injusticia. Podemos indicar tres principales: las personas, el sistema político, Dios.

\subsubsection{Las personas}

Los profetas, al denunciar a los responsables de la injusticia, terminaron identificando a cinco grupos principales: príncipes, jueces, sacerdotes, falsos profetas y terratenientes. En la literatura sapiencial no se advierte un análisis tan detallado de los grupos responsables. En Qohélet encontramos una referencia expresa a los jueces: "Otra cosa observé bajo el sol: en la sede del derecho, el delito; en el tribunal de la justicia, la iniquidad” (3, 16-17).

Pero es más frecuente que se englobe a todos los responsables bajo el título común de malvados, a los que se describe del modo siguiente en Proverbios 30, 11-14:

Gente que maldice a su padre y no bendice a su madre,

gente que se considera limpia y no se lava su inmundicia,

gente de ojos engreídos y mirada altanera,

gente con navajas por dientes y cuchillos por mandíbulas,

para extirpar de la tierra a los humildes y del suelo a los pobres.

Las palabras finales (v. 14) usan unas imágenes potentes y crueles que recuerdan al profeta Miqueas, cuando denuncia a los poderosos que tratan al pueblo como carne de matadero; pero luego, dejándose de metáforas, aluden 
claramente a sus intenciones: acabar con los humildes y los pobres. En opinión de algunos comentaristas, esta fue la gran preocupación del profeta Amós, que veía cómo los campesinos pobres eran despojados de sus tierras y de sus medios de supervivencia. El hecho lo denuncia claramente el profeta Miqueas ("oprimen al hombre y a su familia, al varón y a su heredad"). E Isaías denuncia la redacción entusiasta por parte de los legisladores de normas vejatorias para dejar indefensos a los pobres y apoderarse de los bienes de los huérfanos y viudas (Is 10, 1-2).

La idea de que los malvados, los ricos y poderosos, son los culpables de la situación se encuentra también en Job.

\subsubsection{El sistema político-administrativo: Qohélet}

En 1987 se quejaba Duane A. Garret de que muchos comentaristas de Qohélet habían pasado por alto la importancia de sus ideas sobre el uso y abuso del poder político $^{11}$. Su estudio analiza ocho textos ${ }^{12}$, que la falta de tiempo nos impide considerar. Además, no todos tienen igual importancia para nosotros en este momento. Me limitaré a uno que considero capital: "Si ves en una provincia oprimido el pobre, conculcados el derecho y la justicia, no te extrañes de tal situación: cada autoridad tiene una superior, y una suprema vigila sobre todas" (Ecl 5,7).

¿A qué problema concreto se refiere Qohélet? Estos versículos se han relacionado con el sistema de las satrapías persas o con los monarcas ptolomeos, con los conflictos entre jefes tribales y el gobierno central, con la rivalidad entre diversos burócratas, con la multitud de burócratas, que hacen más elevada la posibilidad de corrupción. En cualquier caso, el sistema político-administrativo es el responsable de la opresión de los pobres y de la conculcación del derecho y la justicia.

\subsubsection{Dios: Job}

La reflexión sapiencial llevó, al menos en el caso de Job, a identificar a un responsable mucho más importante: el mismo Dios. En el capítulo 24, que citamos antes para describir las desgracias de los pobres y la responsabilidad de los malvados, se denuncia de una manera que a algunos podría resultar blasfema: "En la ciudad gimen los moribundos y piden socorro los heridos, y Dios no hace caso de su súplica" $(24,12)$.

De este modo, Job vincula el problema de la injusticia a otro mucho más grave: el problema del mal, y nos obliga a enfocarlo desde un punto de vista teológico. Nosotros nos hemos acostumbrado a culpar de las injusticias de nuestro mundo a las estructuras sociales, económicas y políticas, a las grandes

11. D. A. Garret, "Qohelethon on the Use and Abuse of Political Power", op. cit., pp. 159-177.

12. Se trata de 3, 15c-17; 4, 1-3; 4, 13-16; 5, 7-8; 7, 6-9; 8, 1-8; 8, 9-9, 6; 9, 13-10, 20. 
potencias como Estados Unidos, Rusia o China, según los gustos, al FMI, a las multinacionales... El autor del libro de Job, en la huella de otros teólogos bíblicos, introduce a Dios como la variante principal de esta ecuación.

Habrá personas que se aferren angustiosamente a la doctrina anterior, temiendo perder su fe en Dios y en la justicia divina. Elifaz, uno de los amigos de Job, repite con sus antepasados:

El malvado pasa la vida en tormentos... escucha ruidos que lo espantan; cuando está más tranquilo lo asaltan los bandidos. No confía volver de las tinieblas, porque está reservado para el puñal. Lo destinan a pasto de los buitres y sabe que su día está cercano; el día lóbrego lo aterroriza, la inquietud y la angustia lo atenazan... (Job 15, 20-24).

Pero Job no se contenta con estas frases hechas, contrarias a toda evidencia. Se formula la misma pregunta de Jeremías, aunque más irónicamente: “Por qué siguen vivos los malvados y al envejecer se hacen más ricos?" (Job 21,7). Su respuesta, demasiado larga para citarla, constituye una de las páginas más amargas y realistas del Antiguo Testamento, dibujando el maravilloso bienestar de los que se rebelan contra Dios (21, 8-33). Por eso, el verso final del capítulo representa una crítica radical a toda la sabiduría anterior: "¿Me quieren consolar con vaciedades? Sus respuestas son puro engaño" $(21,34)$.

\section{3. ¿Qué solución entrevén?}

Igual que en el punto anterior, se advierten posturas muy distintas.

\subsubsection{El optimismo}

A menudo se afirma, en parte con razón, que la sabiduría más antigua era profundamente optimista. Por consiguiente, la solución era fácil. Como en una antigua película de buenos y malos, el bueno terminaría siempre triunfando y el malvado castigado ${ }^{13}$.

El justo jamás flaqueará, los malvados no habitarán la tierra (Prov 10, 30).

El justo se libra del peligro y el malvado ocupa su lugar (Prov 11, 8).

Ninguna desgracia alcanza al justo, los malvados están llenos de miserias (Prov 12, 21).

13. Curiosamente, en el escéptico Qohélet podríamos encontrar una especie de optimismo trascendente: "Otra cosa observé bajo el sol: en la sede del derecho, el delito; en el tribunal de la justicia, la iniquidad; y pensé: al justo y al malvado los juzgará Dios" (3, 16-17). Aunque la situación no tenga remedio en esta vida, la tendrá en un mundo futuro. Sin embargo, tal interpretación iría en contra del pensamiento de Qohélet a lo largo de toda su obra. 
El justo come hasta quedar satisfecho, el vientre de los malvados pasa necesidad (Prov 13, 25).

Los malos se inclinan ante los buenos, y los malvados, a la puerta de los justos (Prov 14, 19).

En la casa del justo abunda la riqueza, las rentas del malvado son inestables (Prov 15, 6).

El malvado huye sin que lo persigan, el justo vive confiado como un león (Prov 28, 1).

\subsubsection{El compromiso con la justicia}

Este optimismo será sometido a dura crítica en el libro de Job y en Qohélet, pero también en el de los Proverbios encontramos una visión más realista. Sirva como ejemplo la enseñanza que una reina pagana desconocida transmitió a su hijo Lemuel para prepararlo a ser un buen rey y que ha quedado recogida en el último capítulo del libro:

No es de reyes, Lemuel, no es de reyes darse al vino

ni de príncipes darse al licor,

porque beben y olvidan la ley y pervierten el derecho de los desgraciados.

Da el licor al vagabundo y el vino al afligido:

que beba y olvide su miseria, que no se acuerde de sus penas.

Abre tu boca a favor del mudo, en defensa del desventurado;

abre tu boca y da sentencia justa defendiendo al pobre y al desgraciado

(Prov 31, 4-9).

Esta enseñanza ofrece dos puntos de vista muy distintos. Según el primero, el vagabundo y el afligido, representantes de los seres más pobres, no deben esperar que su situación cambie radicalmente. Seguirán en la miseria, y solo les cabe el consuelo del vino y del licor que les ayuden a olvidar sus penas. En cambio, un segundo punto de vista habla de la responsabilidad del monarca en la defensa de los desgraciados, desventurados y pobres. Con sus sentencias justas, el rey puede ser para ellos un consuelo mucho más duradero y perfecto que el vino y el licor.

Este compromiso de los reyes y los nobles con la justicia es tema frecuente en las obras sapienciales no solo en Israel, sino en todo el Antiguo Oriente. En el libro de los Proverbios se enseña al rey (cc. 28-29) ${ }^{14}$ y a los cortesanos cómo deben comportarse ${ }^{15}$. Dentro de esta serie es importante este proverbio: "Aparta al malvado del rey / y su trono se afianzará en la justicia" $(25,5)$.

14. Especialmente en Prov 28-29. Cf. U. Skladny, Die ältesten Spruchsamlungen in Israel (Göttingen: Vandenhoeck \& Ruprecht, 1962, pp. 58-62), B. V. Malchow, "A Manual for Future Monarchs", Catholic Biblical Quarterly, 47 (1985), 238-245.

15. G. Bryce, "Another Wisdom-'Book' in Proverbs", Journal of Biblical Literature, 91 (1972), 145-57. 


\subsubsection{La limosna}

En la reflexión sapiencial, la limosna adquiere un puesto tan importante que merece un apartado. En la cultura occidental, la limosna está desprestigiada, se la considera insultante. Sin embargo, para los antiguos era algo muy digno, un acto de justicia ${ }^{16}$.

La ayuda al necesitado es algo que se contempla ya en la ley deuteronómica: "Si hay entre los tuyos un pobre, un hermano tuyo, en una ciudad tuya, en esa tierra tuya que va a darte el Señor, tu Dios, no endurezcas el corazón ni cierres la mano a tu hermano pobre. Ábrele la mano y préstale a la medida de su necesidad" (Dt 15, 7-8). Lo que aquí se contempla como mera posibilidad ("si hay...") era de hecho una cruda realidad, y por eso se añadió más tarde la norma siguiente: "Nunca dejará de haber pobres en la tierra; por eso yo te mando: Abre tu mano al pobre, al hermano necesitado que vive en tu tierra" (Dt 15,11). La ley usa una fórmula muy expresiva: "abrir la mano", lo opuesto al puño cerrado, que simboliza la tacañería. Esta metáfora volvemos a encontrarla en el elogio de la buena empresaria y ama de casa: "Abre sus palmas al necesitado y extiende sus manos al pobre" (Prov 31, 20). Y otro proverbio destaca la importancia del tema: "Quien desprecia a su prójimo, peca; dichoso quien se apiada de los pobres" (Prov 14, 21).

La limosna, en el sentido que nosotros le damos, aparece con toda claridad en la novelita bíblica de Tobías, de profundo influjo sapiencial (Tob 4, 7s.16; 12, 8; 13, $8 ; 14,8.10)^{17}$, y en la obra de Jesús ben Sirá, el Eclesiástico (Eclo 3, 30-4, 10; 7 , $10 ; 12,3 ; 29,12 ; 35,2)$. Este autor demuestra enormes reservas ante la riqueza y se pone de parte del pobre, intenta comprender sus necesidades y angustias, e insiste en que Dios está de su parte. Limosna y compasión serán sus principales consejos.

En 3, 30-4, 10 concede especial importancia a las personas pobres que necesitan ayuda económica (afligido, necesitado, abatido, indigente, huérfano, viuda). De los oprimidos víctimas de la injusticia solo habla en 4,9 . No pretende cambiar la sociedad de forma radical. No analiza los motivos de la pobreza y la riqueza. Se limita a constatar lo que ocurre y pone un remedio sencillo, al alcance de todos. Esa actitud tiene una dimensión humanitaria, pero se inspira sobre todo en motivos religiosos: la limosna es una forma de expiar los pecados, de conseguir

16. En hebreo no existe la palabra "limosna", en el sentido que nosotros le damos. Esta viene del griego $\dot{\varepsilon} \lambda \varepsilon \eta \mu о \sigma u ́ v \eta$, que los LXX utilizan para traducir a veces el hebreo cüdäq $\hat{a}$, "justicia”. De este modo, la limosna aparece como un acto de justicia.

17. Baste como botón de muestra la primera cita, en la que Tobit aconseja a su hijo Tobías: "Da limosna de tus bienes a toda la gente honrada y no seas tacaño en tus limosnas. Si ves un pobre, no vuelvas el rostro, y Dios no te apartará su rostro. Haz limosna en proporción a lo que tienes; si tienes poco, no temas dar de lo poco que tienes" (Tob 4, 7-8). 
la ayuda de Dios, ser hijo suyo y conseguir su favor. Por el contrario, desoír al pobre provocará su reacción negativa $(4,6)$.

$3^{30} \quad$ El agua apaga el fuego ardiente y la limosna expía el pecado.

31 Al bienhechor lo recuerdan más tarde, cuando resbale encontrará apoyo.

$4^{1}$ Hijo mío, no te burles de la vida del afligido, no deprimas al que sufre amargamente;

2 no le gruñas al necesitado ni te cierres al ánimo abatido;

3 no exasperes al que se siente abatido ni aflijas al pobre que acude a ti, ni niegues limosna al indigente;

4 no rechaces la súplica del abatido, ni apartes tu rostro del pobre.

$5 \quad$ No apartes tu mirada del necesitado ni le des ocasión de maldecirte:

6 si en la amargura de su dolor clama contra ti, su Hacedor escuchará su clamor.

7 Hazte simpático a la asamblea, inclina la cabeza ante el que manda;

8 haz caso del pobre y responde a su saludo con llaneza;

$9 \quad$ libra al oprimido del opresor y no te repugne hacer justicia.

10 Sé padre para los huérfanos y marido para las viudas, y Dios te llamará hijo, tendrá piedad y te librará de la fosa.

En 29, 1-13 aborda Ben Sirá el tema de la generosidad partiendo de la amarga experiencia de los préstamos. El hombre compasivo presta... y le cuesta infinito recuperar lo prestado, incluso es posible que se gane enemigos. Eso puede provocar que la gente se retraiga de prestar. Pero sé generoso con el pobre. En este contexto, tiene frases muy parecidas a las de Jesús (10-13).

1 Quien presta al prójimo hace obra de misericordia quien le echa una mano guarda los mandamientos.

2 Presta a tu prójimo cuando lo necesita, y paga pronto lo que debes al prójimo

3 cumple la palabra y sele fiel, y en todo momento obtendrás lo que necesitas.

$4 \quad$ Muchos tomaron un préstamo como un hallazgo y perjudicaron al que les prestó:

5 hasta conseguirlo le besan las manos, 
ante las riquezas del prójimo humillan la voz;

a la hora de devolver dan largas

y piden una prórroga.

6 Importunando apenas recobrará la mitad,

y lo considerará un hallazgo;

en otro caso se quedará sin dinero

y se habrá echado un enemigo de balde,

que le pagará con maldiciones e insultos,

con injurias, en vez de honor.

7 Muchos se retraen no por maldad, sino temiendo que los despojen sin razón.

8 Con todo, ten paciencia con el pobre y no le des largas en la limosna;

9 por amor a la Ley recibe al menesteroso, y en su indigencia no lo despidas de vacío;

10 pierde tu dinero por el hermano y el prójimo, no dejes que se oxide bajo una piedra;

11 invierte tu tesoro según el mandato del Altísimo, y te producirá más que el oro;

12 guarda limosnas en tu despensa, y ellas te librarán de todo mal;

13 mejor que escudo resistente o poderosa lanza, lucharán contra el enemigo a tu favor.

\subsubsection{La remisión de deudas}

Hay algo que va más allá de la limosna, y que ataca el problema en su misma raíz: la remisión de deudas que, en la práctica, significa la devolución de la propiedad perdida, de la tierra necesaria para sobrevivir. En el libro del Levítico encontramos la famosa ley del jubileo, que contempla la devolución de las tierras a sus antiguos propietarios empobrecidos al cabo de cincuenta años (Lev 25, 8-17). Una ley tan utópica que probablemente nunca se puso en práctica. En cambio, Nehemías se jacta de haber convencido a sus conciudadanos ricos de devolver a los pobres las tierras de las que se habían apoderado mediante artificios legales (Neh 5).

Dentro de la literatura sapiencial bíblica no aparece este tema, pero sí en la literatura egipcia, y curiosamente en una obra, la Enseñanza de Amenemope, que fue copiada en parte por el libro de los Proverbios. En ella encontramos:

Si el pobre te debe mucho, divídelo en tres partes:

perdona dos y deja solo una.

Esto, ya verás, es lo mejor de esta vida;

a partir de entonces dormirás bien y por la mañana 
todo te parecerá maravilloso;

porque es mejor ser apreciado por amor al prójimo

que tener riquezas almacenadas;

mejor saborear el pan con buena conciencia

que tener riquezas cargadas de reproches (c. XII).

\subsubsection{Eclesiastés. De la solución del placer al "no cabe solución"}

La injusticia social es solo un aspecto del problema para Qohélet. Su visión es mucho más amplia, centrada en el sinsentido de la vida, que culmina en la muerte. Qohélet encuentra una salida al problema, optando por el placer sencillo y cotidiano: "Yo alabo la alegría, porque el único bien del hombre es comer, beber y alegrarse; eso le quedará de sus trabajos durante todos los días de su vida que Dios le conceda vivir bajo el sol" $(8,15)$. No se trata de una frase suelta, sino de un leitmotiv que se repite a lo largo de la obra con fuerza creciente (ver 2, 24; $3,12.22 ; 5,17 ; 9,7-10)$.

Sin embargo, esta solución es imposible para el pobre y oprimido, que no puede permitirse ninguno de esos placeres sencillos. Para él no cabe solución.

También observé todas las opresiones que se cometen bajo el sol: vi llorar a los oprimidos sin que nadie los consolase, sin que nadie los consolase del poder de los opresores; y consideré a los muertos que ya han muerto más dichosos que los vivos que aún viven, y mejor que los dos el que aún no ha existido, porque no ha visto las maldades que se cometen bajo el sol (4, 1-3).

¿Cuáles son las opresiones contempladas y quiénes son los oprimidos ${ }^{18}$ ? Qohélet no lo dice, lo cual se ha prestado a discusión. No parece tratarse de opresión religiosa, de persecución de los judíos fieles, como ocurrirá mucho más tarde, en tiempos de Antíoco Epífanes. Qohélet debe pensar en la opresión socioeconómica. Por entonces, gran parte de la tierra estaba en manos de la corona y de personas que recibían campos confiscados a los judíos. Estos debían pagar como impuesto un tercio del grano recogido y la mitad de los frutos. Pero estos cálculos matemáticos se prestan a una mala interpretación. Lo que quiere decir Qohélet no es que a los oprimidos les quedan dos tercios del grano y la mitad de los frutos. Lo que les queda es una miseria, que los hace llorar sin que nadie los consuele. Ni siquiera los profetas habían demostrado tanta simpatía con el sufrimiento de los pobres. Sin embargo, a diferencia también de los profetas, Qohélet no grita en defensa de los necesitados, no reivindica un cambio o una revolución social. Las maldades que se cometen bajo el sol no tienen remedio, y lo único que cabe es felicitar a los muertos y, más aún, a los que no han nacido.

18. Ver A. Pinker, "The Oppressed in Qohelet 4:1", Vetus Testamentum, 61 (2011), 393-405. 
El contraste entre "cabe solución al sinsentido de la vida" y "no cabe solución a la injusticia" deja entrever uno de los peligros más graves del intelectual: cerrarse en su propio mundo, encontrar una escapatoria a su propia angustia y lamentarse de la desgracia del pobre, sin comprometerse por cambiar mínimamente la sociedad.

\section{3. ¿Qué pretenden enseñar?}

Podríamos agrupar la enseñanza de los sabios en tres grandes apartados: verdades generales (valor de la justicia, peligro de la riqueza), normas de recta conducta (como hemos visto en el apartado anterior) y una correcta idea de Dios. Los dos primeros son bastante conocidos y tratados. En cambio, conviene detenerse en el tercero.

En los consejos de la madre de Lemuel a su hijo, que habría firmado con gusto el profeta Jeremías, resulta curioso que la reina nunca mencione a sus dioses. Se basa en una sabiduría puramente humana. Esto no era frecuente en el Antiguo Oriente, donde se solía vincular la práctica de la justicia con los dioses, en concreto con uno de ellos (Utu o Shamash, en ambiente mesopotámico). Debido al monoteísmo, en Israel no hay un dios de la justicia entre otros muchos, sino un solo dios, Yahvé, que es justo y ama la justicia.

Los proverbios bíblicos se orientan en esta línea. Para comprender lo que sigue, conviene recordar lo que decía el profeta Oseas sobre el conocimiento de Dios. Para él, conocer a Dios equivale a practicar la justicia, preocuparse por los más débiles y oprimidos. La explicación es muy sencilla: esas personas son las predilectas de Dios, que escucha siempre el clamor de los oprimidos, igual que escuchó el clamor de su pueblo en Egipto. Por eso, quien practica la justicia conoce a Dios, sabe lo que a él le gusta. En cambio, quien piensa que Dios se contenta con peregrinaciones, ofrendas y sacrificios de animales, desconoce a Dios. Esta idea, que parece típica de los profetas, se encuentra también en los autores sapienciales. Una serie de proverbios hablan de la predilección de Dios por los pobres ${ }^{19}$, de su deseo de que se ayude al necesitado ${ }^{20}$. El Señor detesta

19. "El Señor arranca la casa del soberbio y planta los linderos de la viuda" $(15,25)$. "Quien explota al necesitado afrenta a su Hacedor, quien se apiada del pobre, lo honra" $(14,31)$. "Quien se burla del pobre afrenta a su Hacedor, quien se alegra de la desgracia no quedará impune" $(17,5)$. "No explotes al pobre, porque es pobre; no atropelles al desgraciado en el tribunal, porque el Señor defenderá su causa y despojará de la vida a los que lo despojan" $(22,22-23)$.

20. "Quien se apiada del pobre presta al Señor, y él le dará su recompensa" $(19,17)$. "El que da al pobre no pasará necesidad, el que se desentiende se llenará de maldiciones" $(28,27)$. 
toda forma de injusticia ${ }^{21}$, y expresamente la injusticia que se comete en el comercio, que afecta de manera especial a los más pobres ${ }^{22}$.

Todo esto culmina en una idea que generalmente se considera típica de los profetas: Dios prefiere la justicia a los sacrificios: "Practicar el derecho y la justicia Dios lo prefiere a los sacrificios" $(21,3)$. "El Señor aborrece el sacrificio del malvado, la oración de los rectos alcanza su favor" $(15,8)$.

Esta contraposición del culto y de la justicia ocupa un puesto destacado en Eclesiástico 34, 18-35, 26, donde podemos distinguir tres partes (34, 18-26; 35 , 1-10; 35, 14-26). La primera habla de los sacrificios que no acepta Dios, la segunda, del culto que a Dios agrada, y la tercera vuelve al tema de los sacrificios injustos y exalta la relación de Dios con los pobres.

La primera parte sería un buen comentario de Isaías 1, 10-17, que habla de la gente que pretende unir festividad e iniquidad, sacrificios y homicidios, gente que tiene las manos manchadas de sangre. Esta gente roba a los pobres, quita el sustento al prójimo y no paga el justo salario. Luego, parte de lo robado lo dedica a ofrecer sacrificios. Contra esta falsa idea de Dios y del culto se levanta el autor indicando que no sirve de nada.

18 Sacrificios de posesiones injustas son impuros, ni son aceptados los dones de los inicuos;

19 el Altísimo no acepta las ofrendas de los impíos ni por sus muchos sacrificios les perdona el pecado;

20 es sacrificar un hijo delante de su padre quitar a los pobres para ofrecer sacrificio.

21 El pan de la limosna es vida del pobre, el que se lo niega es homicida;

22 mata a su prójimo quien le quita el sustento, quien no paga el justo salario derrama sangre.

23 Uno construye y otro derriba: ¿de qué sirve sino de más trabajo?

24 Uno reza y otro maldice: ¿a quién escuchará el Señor?

21. "Seis cosas detesta el Señor y una séptima la aborrece de corazón: ojos engreídos, lengua embustera, manos que derraman sangre inocente, corazón que maquina planes malvados, pies que corren para la maldad, testigo falso que profiere mentiras y el que siembra discordias entre hermanos" $(6,16)$. "Al que absuelve al culpable y al que condena al inocente, a los dos los aborrece el Señor" $(17,15)$.

22. "El Señor aborrece las balanzas falsas y le gustan las pesas exactas" $(11,1)$. "Pesas desiguales, medidas desiguales: las dos cosas las aborrece el Señor" (20, 10). "El Señor aborrece pesas desiguales, no es justa la balanza con trampa" $(20,23)$. 
25 Uno se purifica del contacto de un cadáver y lo vuelve a tocar: ¿de qué le sirve el baño?

26 Lo mismo el que ayuna por sus pecados y luego vuelve a cometerlos, ¿quién escuchará su súplica?, ¿de qué le servirá su mortificación?

La segunda parte $(35,1-10)$ habla del culto agradable a Dios. Ante todo, observar la Ley y guardar los mandamientos: esa es la mejor ofrenda y el mejor sacrificio. En segundo lugar, la limosna, que es como la ofrenda y la acción de gracias. En tercer lugar, apartarse del mal y de la injusticia: la conducta ética, que es como el sacrificio de expiación. Después de estos tres aspectos, pasa el autor a hablar de las ofrendas, sacrificios y diezmos. Cuando se da lo anterior, tienen pleno sentido y han de ser lo más generosos posible.

1 El que observa la Ley hace una buena ofrenda, el que guarda los mandamientos ofrece sacrificio eucarístico,

2 el que hace favores ofrenda flor de harina, el que da limosna ofrece sacrificio de alabanza.

3 Apartarse del mal es agradable a Dios, apartarse de la injusticia es expiación.

$4 \quad$ No te presentes a Dios con las manos vacías: esto es lo que pide la Ley.

5 La ofrenda del justo enriquece el altar, y su aroma llega hasta el Altísimo.

6 El sacrificio del justo es aceptado, su ofrenda memorial no se olvidará.

7 Honra al Señor con generosidad y no seas mezquino en tus ofrendas;

8 cuando ofreces, pon buena cara, y paga de buena gana los diezmos.

9 Da al Altísimo como él te dio: generosamente, según tus posibilidades,

10 porque el Señor sabe pagar y te dará siete veces más.

La tercera parte $(35,14-26)$ vuelve al tema de los sacrificios injustos, denunciando la falsa idea de Dios que presuponen.

14 No lo sobornes, porque no lo acepta, no confíes en sacrificios injustos;

15 porque es un Dios justo que no puede ser parcial;

16 no es parcial contra el pobre, escucha las súplicas del oprimido;

17 no desoye los gritos del huérfano o de la viuda cuando repite su queja; 
18 mientras le corren las lágrimas por las mejillas

19 y el gemido se añade a las lágrimas,

20 sus penas consiguen su favor y su grito alcanza las nubes;

21 la reclamación del pobre atraviesa las nubes y hasta alcanzar a Dios no descansa; no ceja hasta que Dios le atiende, y el juez justo le hace justicia.

22 Dios tampoco dará largas; como guerrero, no reposará,

23 hasta quebrantar los lomos del tirano y tomar venganza de los soberbios, hasta arrancar el cetro de los arrogantes y romper la vara de los malvados,

24 hasta pagar al hombre sus acciones y retribuir al mortal sus pensamientos,

25 hasta defender la causa de su pueblo y darles la alegría de la salvación.

26 Bienvenida su misericordia en la tribulación, como chaparrón durante la sequía.

\section{Conclusiones}

La presentación de los textos demuestra que la preocupación por la justicia fue una constante entre los sabios de Israel. Entre ellos no existió el intelectual que se desentiende de este tipo de problemas. Esto no representa una peculiaridad exclusiva de los autores bíblicos. En esto coinciden con todos los sabios del Antiguo Oriente, que se esfuerzan por educar a los reyes y a la nobleza, generalmente sin éxito, para que defiendan a los pobres y gobiernen justamente.

Al mismo tiempo, queda claro que no hay entre los sabios de Israel una postura uniforme, ni en el modo de describir la realidad social en la que viven, ni en las causas de la injusticia, ni en los posibles remedios. Pero esto no debe asombrarnos. También entre los profetas advertimos las mismas diferencias ${ }^{23}$.

Finalmente, concedo especial importancia al acuerdo entre algún Proverbio y el libro del Eclesiástico con los profetas, a propósito de la recta idea de Dios: un Dios amante y defensor de los pobres, que nos exige luchar por un mundo más justo, aunque esa lucha pueda terminar a veces en el martirio.

23. Para este tema me remito a mi obra "Con los pobres de la tierra". La justicia social en los profetas de Israel (Madrid: Ediciones Cristiandad, 1984). Una presentación breve, con la bibliografía actualizada, en J. L. Sicre, Introducción al profetismo bíblico (Estella: Verbo Divino, 2011, cap. 26: "La lucha por la justicia”, pp. 395-417). 